https://doi.org/10.36105/iut.2020n32.08

\title{
A JUSTIÇA MILITAR BRASILEIRA E SUA IMPORTÂNCIA PARA O ESTADO DEMOCRÁTICO DE DIREITO
}

\author{
LA JUSTICIA MILITAR BRASILEÑA Y SU IMPORTANCIA \\ PARA EL ESTADO DE DERECHO DEMOCRÁTICO
}

\section{BRAZILIAN MILITARY JUSTICE AND ITS IMPORTANCE FOR THE DEMOCRATIC STATE OF LAW}

\author{
Maria Elizabeth Guimarães Teixeira Rocha* \\ Investigadora independiente, Brasil \\ bethgtr@gmail.com
}

\section{RESUMEN:}

En este artículo se hace un repaso histórico sobre la institucionalidad de la Corte Suprema de Justicia Brasileña, así como sobre la importancia para el estado de derecho de la justicia militar, estableciéndose con detalle sus competencias, retos futuros y las áreas de oportunidad que deben de ser enfrentadas en el futuro cercano por las instituciones.

\section{Palabras clave:}

Justicia Militar, Brasil, Corte Suprema de Justicia Militar, Estado democrático de derecho.

\section{ABSTRACT:}

This article provides a historical review of the institutionality of the Brazilian Supreme Court of Justice, as well as the importance of military justice for the rule of law, establishing in detail its competences, future challenges and the areas of opportunity that must be addressed. be faced in the near future by the institutions.

Keywords:

Military Justice, Brasil, Military Supreme Court, Democratic rule of law.

* Ministra e Ex-Presidente do Superior Tribunal Militar. Doutora em Direito Constitucional pela Universidade Federal de Minas Gerais. Doutora honoris causa pela Faculdade Inca Garcilaso de la Vega -(Lima, Perú). Mestre em Ciências Jurídico-Políticas pela Universidade Católica Portuguesa - (Lisboa, Portugal). Professora Universitária. Autora de livros e artigos jurídicos publicados no Brasil e no exterior. 
A Magna Corte Castrense, conforme narra a historiografia pátria, foi instituída em $1^{\circ}$ de abril de 1808 , por Alvará com força de lei, assinado pelo Príncipe-Regente D. João, com a denominação de Conselho Supremo Militar e de Justiça. ${ }^{1}$ Por volta de 1891, instituiu-se o Supremo Tribunal Militar, com as mesmas competências do extinto Conselho Supremo Militar e após o advento da Constituição de 1946 (art. 106), adquiriu a terminologia atualmente adotada: Superior Tribunal Militar.

Ao longo dos anos, a composição da Corte Militar no Brasil sofreu diversas alterações até chegar ao atual número de quinze magistrados, civis e militares. A despeito das modificações numéricas no seu quorum, ${ }^{2}$ a composição mista sempre se fez presente. Efetivamente, o instituto do escabinato foi consagrado na Justiça Militar tendo em vista as peculiaridades da vida na caserna, donde decorre a necessidade de mesclar a experiência dos comandantes com o saber jurídico dos togados. ${ }^{3}$

Consubstanciando mais de 200 anos de História, foi ela integrada ao Poder Judiciário pela Carta Política de 1934, decorrência da vontade soberana da Assembléia Nacional Constituinte.

Como Justiça especializada, acoberta uma categoria especial de agentes, impulsionando a aplicação da lei militar às Forças Armadas - Marinha, Exército e Aeronáutica - e julga, tão somente, os crimes militares definidos em lei, preceito emanado do art. 124 da Constituição Federal.

1 O Conselho Supremo Militar e de Justiça visava manter a ordem e a disciplina no âmbito militar. "Acumulava o referido órgão duas funções: uma de caráter administrativo, coadjuvando o governo em questões referentes a requerimentos, cartas-patentes, promoções, soldos, reformas, nomeações, lavratura de patentes e uso de insígnias, sobre as quais manifestava seu parecer, quando consultado; outra de caráter puramente judiciário.Como Tribunal Superior de Justiça Militar, o Conselho Supremo julgava em última instância os processos criminais dos réus sujeitos ao foro militar.

O Conselho Supremo Militar era integrado pelos Conselheiros de Guerra e do Almirantado e por outros oficiais que fossem nomeados como Vogais, os quais a maioria das vezes galgavam as posições de Conselheiros de Guerra.

O Conselho Supremo de Justiça possuía a mesma composição, acrescentando-se-lhe, porém, três juízes togados, um dos quais para relatar os processos." Superior Tribunal Militar. 173 Anos de História. Trabalho elaborado por Paulo César Bastos, Brasília, 1981, p. 21.

2 A composição da Justiça Militar da União variou ao longo da História Brasileira. Originariamente era integrada por 13 magistrados, conforme o Alvará instituidor datado de $1^{\circ}$ de abril de 1808 . Em 1850 passaram a 15 os seus membros, número mantido com o advento da República pelo Decreto $n^{\circ}$. 149, de 18 de julho de 1893. Posteriormente, o Decreto $\mathrm{n}^{\circ}$. 17.231-A, de 26 de fevereiro de 1926 reduziria este número para 10 , ampliado depois para 11 pela Constituição de 1934, Constituição sob cuja égide a Justiça Militar foi inserida na estrutura do Poder Judiciário. Com a promulgação do Ato Institucional nº. 2, de 5 de novembro de 1965, o já denominado Superior Tribunal Militar, voltou a ter quinze ministros vitalícios, composição mantida pelas Cartas de 1967/69 e pela Lei Maior vigente, promulgada em 1988. No transcurso da história brasileira, a Justiça Militar foi presidida por personagens marcantes tais como; os Marechais Deodoro da Fonseca e Floriano Peixoto

3 No dizer de Astor Nina de Carvalho Júnior: "O bom magistrado militar não é aquele que necessariamente conhece bem o ordenamento jurídico pátrio, mas aquele que além de conhecer bem o direito militar, conhece o funcionamento e o cotidiano dos quartéis, pois o juiz, mesmo imparcial, não se pode quedar distante dos anseios e valores sociais, sob pena de julgar mal e não traduzir o sublime ideal de justiça". In: A segunda etapa da reforma do judiciário e o novo perfil do Superior Tribunal Militar. Revista de Direito Militar, v.10, no. 61, p.18. 
Prevê a Lei Maior duas espécies de Justiças Militares: a federal e a estadual, ex vi dos artigos 122 a 124 e $125 \S \S 3^{\circ}, 4^{\circ}, 5^{\circ}$, respectivamente, inseridos no Título II, Capítulo III, do Poder Judiciário - Seção VII - Dos Tribunais e Juízes Militares. No tocante à esfera federal, são órgãos da Justiça Militar da União consoante estatui o art. 122 da Constituição Pátria, o Superior Tribunal Militar, os Tribunais e juízes militares, instituídos por lei. A previsão constitucional é regulamentada pela Lei 8.457 , de 4 de setembro de 1992, e alterações, que organiza a Justiça Militar da União e regula o funcionamento de seus serviços auxiliares.

Com jurisdição em todo o território nacional, encontra-se o Superior Tribunal Militar na cúpula da estrutura hierárquica do Judiciário Castrense e é composto por 15 Ministros vitalícios - três dentre Oficiais-Generais da Marinha, quatro dentre Oficiais-Generais do Exército e três dentre Oficiais-Generais da Aeronáutica, todos da ativa e do posto mais elevado da carreira; e cinco civis - três advogados de notório saber jurídico e conduta ilibada, com mais de dez anos de efetiva atividade profissional e dois por escolha paritária dentre juízes federais da Justiça Militar e membros do Ministério Público Militar. Todos os magistrados são nomeados pelo Presidente da República após aprovação do Senado Federal.

Preservou a vigente Carta Política o escabinato ou escabinado, instituto mediante o qual, magistrados militares e cíveis togados integram o mesmo Tribunal ou Juízo. Preservou-o em razão dele "permitir aliar a experiência dos comandantes que atingiram o ápice das carreiras, acumulando mais de quarenta anos de vida na caserna, com o inegável conhecimento jurídico dos ministros civis." ${ }^{4}$ Dessa forma, a Justiça Castrense, garante "uma aplicação justa e humana do direito militar," na lição do Ministro Carlos Alberto Marques Soares. ${ }^{5}$

No tocante à competência, cabe às auditorias e ao Superior Tribunal Militar processar e julgar os crimes militares definidos em lei, a teor do art.124 da Constituição Federal. ${ }^{6}$ A referida lei, invocada pela Lex Magna, é o Código Penal

4 In: A Justiça Militar da União. Conferência realizada para Oficiais-Generais e Oficiais Superiores das Forças Armadas da República de Angola, em 19 de julho de 2006, pelo Ministro Tenente-Brigadeiro-do-Ar Henrique Marini e Souza.

5 In: Justiça Militar da União: 200 Anos. Palestra proferida em Comemoração ao Bicentenário da Justiça Militar Federal, na Auditoria da $9^{\text {a }}$ Circunscrição Judiciária Militar, na cidade de Campo Grande, Mato Grosso do Sul, em 13 de junho de 2008.

6 Cumpre rememorar lição de João Barbalho a propósito da Justiça Militar cujo foro é competente para processar e julgar os crimes militares e não, os crimes dos militares. Leia-se: “(...) o foro especial é para o soldado, ut miles, na phrase do jurisconsulto romano (...).

Para os crimes previstos pela lei militar uma jurisdição especial deve existir, não como privilégio dos indivíduos que os praticam, mas atentta à natureza desses crimes e à necessidade, a bem da disciplina, de uma repressão prompta e firme, com fórmas summarias.

A existência das forças militares liga-se à existência da nação, como garantia de sua independência e segurança, e sem uma exacta e constante disciplina não cumprirão ellas seo importante fim.

Sem disciplina não há subordinação nem segurança; ella é a vida e a força dos exércitos. E sem uma jurisdição própria, privativa, militar também, essa disciplina seria impossivel.

Além d'isso, a infracção do dever militar por ninguém pode ser melhor apreciada do que por militares mesmo; elles, mais que os estranhos no serviço das forças armadas, sabem compreender a gravidade da violação e as circunstâncias que podem modifica-la. 
Militar promulgado em 1969, cujos artigos $9^{\circ}$ e $10^{\circ}$ estatuem sobre os crimes militares em tempo de paz e em tempo de guerra. ${ }^{7}$ Trata-se, portanto, de uma Justiça destinada a julgar, exclusivamente, os crimes militares, cometidos tanto por militares e assemelhados, ${ }^{8}$ quanto por civis.

Em se tratando do Superior Tribunal Militar, atua como instância originária e recursal. Na qualidade de Corte de Apelação, compete-lhe apreciar os recursos interpostos contra as decisões do Juízo a quo. Seus acórdãos são definitivos, só cabendo interposição, para o Supremo Tribunal Federal, de recurso extraordinário, quando versar sobre questão constitucional - art. 102, III, "a", "b", "c" da CF - e de recurso ordinário em habeas corpus ou mandado de segurança, quando denegatória a decisão - art. 102, II, "a".

Originariamente, cabe-lhe processar e julgar os oficiais-generais das Forças Armadas acusados em ações penais - art. $6^{\circ}$, I, da Lei $n^{\circ} 8.457 / 92$-, bem como os mandados de segurança contra seus próprios atos, os do Presidente do Tribunal e os de outras autoridades da Justiça Militar. Compete-lhe ainda, nesta sede, conhecer e decidir sobre as representações para decretação de indignidade de oficial ou sua incompatibilidade com o oficialato - art. 142, $\S 3^{\circ}$, VI, da CF e os feitos dos Conselhos de Justificação - art. 142, $\S 3^{\circ}$, VII da CF.

Concernente à primeira instância, esta é constituída por doze Circunscrições Judiciárias Militares, sendo que em cada uma funciona uma Auditoria, à exceção da primeira ( $\left.1^{\mathrm{a}} \mathrm{CJM}\right)$, sediada no Rio de Janeiro, que possui quatro, da segunda $\left(2^{\mathrm{a}}\right.$ CJM), sediada em São Paulo, que dispõe de duas e da terceira ( $\left.3^{\mathrm{a}} \mathrm{CJM}\right)$, sediada em Porto Alegre, que conta com três. As áreas territoriais das Circunscrições Judiciárias Militares correspondem às Regiões Militares que detêm maior concentração

E assim o foro especial é uma condição de boa administração da Justiça.". BARBALHO, João. Constituição Federal Brasileira - Comentários. 2a ed., 1924.Rio de Janeiro: Briguiet e Cia. Editores. p. 466.

7 Crimes Militares são infrações que deturpam os alicerces básicos e específicos da ordem e disciplina militar, que olvidam e corroem, com o seu aperfeiçoamento, obrigações e deveres do militar. Esse raciocínio é compartilhado por Célio Lobão quando assevera "o crime militar é a infração penal prevista na lei penal militar que lesiona bens ou interesses vinculados à destinação constitucional das instituições militares, às suas atribuições legais, ao seu funcionamento, à sua própria existência, no aspecto particular da disciplina, da hierarquia, da proteção à autoridade militar e ao serviço militar”. LOBÃO, Célio. Direito Penal Militar. 3. ed. Brasília: Brasília Jurídica, 2006, p. 56.

Cabe ressaltar que a doutrina e jurisprudência estabelecem uma diferenciação entre os crimes militares, distinguindo-os em crimes propriamente e impropriamente militares. Consoante acentua Esmeraldino Bandeira, a classificação do delito em propriamente militar se traduz naquele crime que tão-somente o soldado pode cometer, visto que diz respeito à vida militar, considerada no conjunto da qualidade funcional do agente, da materialidade especial da infração e da natureza peculiar do objeto danificado, isto é, o serviço, a disciplina, a administração ou a economia militar. Esmeraldino Bandeira. Direito, Justiça e Processo Militar. $1^{\circ}$. Vol. Francisco Alves, Rio de Janeiro, 1919, p. 26. No que tange aos crimes impropriamente militares cabe trazer a lume a lição de Celso Lobão quando ensina que “(...) é a infração penal prevista no Código Penal Militar que, não sendo 'especifica e funcional da profissão do soldado', lesiona bens ou interesses militares relacionados com a destinação constitucional e legal das instituições castrenses.” LOBÃO, Celso, op. cit., p. 98.

8 "Assemelhado é o indivíduo que não sendo militar está sujeito à subordinação, disciplina e jurisdição militar, em virtude de exercer uma função especifica disciplinada em lei (médicos, dentistas, engenheiros) nas Forças Armadas, bem como as pessoas que trabalham em navios, quartéis, fortes, que aos civis se equiparam, desde que subordinados à disciplina militar." BASTOS, Celso Ribeiro, op. cit., p. 496. 
de contingentes do Exército Brasileiro. Dentro das Auditorias funcionam os Conselhos de Justiça que podem ser de dois tipos: o Permanente e o Especial.

Os Conselhos Permanentes de Justiça julgam as praças de suas respectivas Forças - soldados, cabos, sargentos e suboficiais nos crimes militares definidos em lei. Deste modo, existem Conselhos de Justiça Permanentes para a Marinha, Exército e Aeronáutica. Compõem-se de quatro juízes militares e um juiz civilo Juiz federal da Justiça Militar que o preside. Os juízes militares servem ao órgão durante um período de três meses, vedada, por regra, a recondução para o trimestre subseqüente. ${ }^{9}$ Eles são designados mediante sorteio, dentre os oficiais que se encontram sediados na área de jurisdição de cada uma das Circunscrições Judiciárias Militares.

Os Conselhos Especiais de Justiça, por seu turno, julgam os oficiais graduados - dos tenentes aos coronéis - denunciados pela prática de crime militar e funcionam da mesma maneira que os Conselhos Permanentes. Em tais Conselhos, os postos e as graduações dos juízes militares deverão ser mais elevados do que a do oficial acusado e eles funcionam durante o período de tempo necessário ao julgamento do militar que estiver sendo processado, não se renovando trimestralmente.

Sobre as competências atuais do Juiz federal da Justiça Militar, por ocasião da nova Lei $n^{\circ} 13.774$, de 20/12/2018, abordarei adiante.

Cumpre informar que, em cada Auditoria, encontram-se investidos dois juízes federais da Justiça Militar, titular e substituto, ingressos na magistratura mediante concurso público de provas e títulos, e que exercem funções judicantes idênticas. ${ }^{10}$ Compete ao Superior Tribunal Militar nomeá-los e promovê-los e, em se tratando de promoção ao cargo de titular, ela ocorre dentre os juízes federais da Justiça Militar substitutos e observará os critérios de antiguidade e merecimento, alternadamente, a teor do disposto no art. 36 da Lei $\mathrm{n}^{\circ} 8.457 / 92$, alterada pela Lei $\mathrm{n}^{\circ} 13.774$, de 2018. O Tribunal somente poderá recusar o magistrado mais antigo pelo voto de dois terços de seus membros, repetindo-se a votação até fixarse a indicação. Em havendo simultaneidade na posse, a promoção por antiguidade recairá preferencialmente sobre aquele que obteve melhor classificação no

9 In: A Jurisdição Cível da Justiça Militar:abrangência e limites dessas nova competência, tanto a nível federal como estadual. Necessidade de reestruturação da Justiça Militar da União. Palestra proferida pelo Ministro José Coelho Ferreira no I Seminário Jurídico ESMPU/MPM - Paraná e Rio Grande do Sul, na cidade de Curitiba, em 28 de setembro de 2006.

10 Conforme salienta Celso Ribeiro Bastos: “A primeira investidura na carreira da magistratura da Justiça Militar se dá no cargo de juiz auditor substituto, mediante concurso público de provas e títulos organizado e realizado pelo Superior Tribunal Militar. Em todas as fases do concurso exige-se a participação da Ordem dos Advogados do Brasil (art. 33 da Lei $n^{\circ}$ 8.457/92). Os candidatos deverão ser brasileiros, ter mais de vinte e cinco e menos de quarenta anos de idade (salvo se já ocupante de cargo ou função pública), estar no gozo dos direitos políticos, ser bacharel em Direito graduado por estabelecimento oficial ou reconhecido, ter exercido, no mínimo, durante três anos, no último decênio, advocacia, magistério jurídico em nível superior ou função que confira prática forense, ser moralmente idôneo e gozar de boa saúde física (...). O concurso terá validade por dois anos, contados da homologação, prorrogável uma vez, por igual período (art. 34, Lei $n^{\circ}$ 8.457/92) '. In: BASTOS, CELSO Ribeiro e MARTINS, Ives Gandra. Comentários à Constituição Brasileira (promulgada em 5 de outubro de 1988), $4^{\circ}$ Volume, Tomo III- Arts. 92 a 126. São Paulo:Saraiva, $2^{\mathrm{a}}$ edição, atualizada, 2000, p. 484. 
concurso de ingresso na carreira. Outrossim, é obrigatória a promoção de juiz que figure por três vezes consecutivas, ou cinco alternadas, em lista de merecimento, desde que conte dois anos de efetivo exercício e integre a primeira quinta parte da lista de antiguidade. A promoção por merecimento obedece aos critérios de presteza e segurança no exercício da judicância, bem como a freqüência e o aproveitamento do magistrado em cursos de aperfeiçoamento; critério este aferido no efetivo exercício do cargo.

Dentre as incompatibilidades, estatui o diploma retro mencionado não poderem servir, conjuntamente, os magistrados, membros do Ministério Público e advogados que sejam entre si cônjuges, parentes consangüíneos ou afins em linha reta, bem como colateral, até o terceiro grau, e os que tenham vínculo de adoção.

Tais incompatibilidades se resolvem: antes da posse, contra o último nomeado ou contra o menos idoso, se as nomeações forem da mesma data e, depois da posse, contra quem lhe deu causa e contra o mais moderno, se a incompatibilidade for imputada a ambos. Por fim, se a incompatibilidade se der com o advogado, ele deverá ser substituído.

Junto à primeira instância atuam, ademais, como de resto, junto ao Superior Tribunal Militar, representantes do Ministério Público Militar que funcionam nas causas como custus legis ou dominus litis, advogados constituídos e defensores públicos ou dativos.

Enfatize-se, por oportuno, ser a ação penal pública, iniciando-se com o recebimento da denúncia ofertada pelo Ministério Público Militar. Inexiste o pagamento de custas processuais. O oferecimento da denúncia, normalmente, é fundado em um Auto de Prisão em Flagrante, em uma Instrução Provisória de Deserção ou em um Inquérito Policial Militar.

Sinteticamente, este é o funcionamento da Justiça Militar em tempo de paz, sendo outra sua atuação, em tempo de guerra. ${ }^{11}$

11 Definem os artigos $9^{\circ}$ e $10^{\circ}$ do Código Penal Militar, os crimes militares em tempo de paz e os crimes militares em tempo de guerra. Verbis:

Art. $9^{\circ}$ Consideram-se crimes militares, em tempo de paz:

I - os crimes de que trata este Código, quando definidos de modo diverso na lei penal comum, ou nela não previstos, qualquer que seja o agente, salvo disposição especial;

II - os crimes previstos neste Código, embora também o sejam com igual definição na lei penal comum, quando praticados:

a) por militar em situação de atividade ou assemelhado, contra militar na mesma situação ou assemelhado;

b) por militar em situação de atividade ou assemelhado, em lugar sujeito à administração militar, contra militar da reserva, ou reformado, ou assemelhado, ou civil;

c) por militar em serviço ou atuando em razão da função, em comissão de natureza militar, ou em formatu$\mathrm{ra}$, ainda que fora do lugar sujeito à administração militar contra militar da reserva, ou reformado, ou civil; d) por militar durante o periodo de manobras ou exercício, contra militar da reserva, ou reformado, ou assemelhado, ou civil;

e) por militar em situação de atividade, ou assemelhado, contra o patrimônio sob a administração militar, ou a ordem administrativa militar;

III - os crimes praticados por militar da reserva, ou reformado, ou por civil, contra as instituições militares, considerando-se como tais não só os compreendidos no inciso I, como os do inciso II, nos seguintes casos: a) contra o patrimônio sob a administração militar, ou contra a ordem administrativa militar;

b) em lugar sujeito à administração militar contra militar em situação de atividade ou assemelhado, ou contra funcionário de Ministério militar ou da Justiça Militar, no exercício de função inerente ao seu cargo; 
Isto porque, previu o legislador um duplo sistema de organização da Justiça Militar em períodos de paz ou de conflitos armados. Nesse diapasão, o Código Penal Militar tipifica os crimes cometidos na guerra ou na paz. Pode-se afirmar que a lei material castrense é a única espécie normativa que tem eficácia parcial, vez a aplicabilidade de seus dispositivos condicionarem-se à situação na qual se encontra o país.

Salienta o Ministro Marcos Augusto Leal de Azevedo que, "em tempo de guerra, compõem a Justiça Militar, junto às forças em operações, os juízes federais da Justiça Militar, os Conselhos de Justiça Militar e os Conselhos Superiores de Justiça Militar (art. 89 da Lei nº 8.457/92). Estes órgãos processam e julgam os crimes praticados em teatros de operações ou em território estrangeiro militarmente ocupado por forças brasileiras, salvo o que dispuserem os tratados e as convenções internacionais nos quais o Estado seja signatário.

Ao Juiz federal da Justiça Militar compete presidir a instrução criminal nos processos em que forem réus, praças, civis ou oficiais até o posto de capitão-demar-e-guerra ou coronel, inclusive, bem como julgar praças e civis.

O Conselho de Justiça é composto de um juiz federal da Justiça Militar ou juiz federal da Justiça Militar substituto e dois oficiais mais antigos que o acusado. Similarmente aos Conselhos Especiais (em tempo de paz), o Conselho de Justiça é constituído para cada processo e dissolvido após o julgamento. Cabe-lhe o julgamento de oficiais, excetuados os oficiais-generais.

O Conselho Superior de Justiça é órgão de segunda instância, composto de dois oficiais-generais, em serviço ativo ou da reserva convocados, e um juiz federal da Justiça Militar, todos nomeados pelo Presidente da República. A presidência é exercida pelo juiz federal da Justiça Militar. Compete a este Conselho, em síntese, processar e julgar oficiais-generais e as apelações advindas dos Conselhos de Justiça.

Junto a ele, funcionam um procurador e um defensor público, também nomeados pelo Presidente da República, dentre os membros do Ministério Público Militar e da Defensoria Pública da União, respectivamente.

c) contra militar em formatura, ou durante o periodo de prontidão, vigilância, observação, exploração, exercicio, acampamento, acantonamento ou manobras;

d) ainda que fora do lugar sujeito à administração militar, contra militar em função de natureza militar, ou no desempenho de serviço de vigilância, garantia e preservação da ordem pública, administrativa ou judiciária, quando legalmente requisitado para aquele fim, ou em obediência a determinação legal superior.

Art. 10. Consideram-se crimes militares, em tempo de guerra:

I- os especialmente previstos neste Código para o tempo de guerra;

II- os crimes militares previstos para o tempo de paz;

III- os crimes previstos neste Código, embora também o sejam com igual definição na lei penal comum ou especial, quando praticados, qualquer que seja o agente:

a) em território nacional, ou estrangeiro, militarmente ocupado;

b) em qualquer lugar, se comprometem ou podem comprometer a preparação, a eficiência ou as operações militares ou, de qualquer outra forma, atentam contra a segurança externa do País ou podem expô-la a perigo;

IV- os crimes definidos na lei penal comum ou especial, embora não previstos neste Código, quando praticados em zona de efetivas operações militares ou em território estrangeiro, militarmente ocupado. 
Em linhas gerais, são essas as características da Justiça Militar em tempo de guerra." ${ }^{12}$ (atualizado com as alterações da Lei $n^{\circ} 13.774 / 2018$ ).

\title{
A JUSTIÇA MILITAR DA UNIÃO E AS ATUALIZAÇÕES LEGAIS
}

\author{
Contempla o art. $125, \S \S 3^{\circ}, 4^{\circ}$ e $5^{\circ}$ da Constituição Federal, a previsão de
} instituírem-se nos estados-membros a justiça militar estadual para julgar os delitos militares definidos em lei cometidos pelos membros das Forças Auxiliares — policiais militares e bombeiros_- e as ações judiciais contra atos disciplinares militares. ${ }^{13}$ Ao contrário da Justiça Militar Federal, não compete à justiça estadual

12 In: A cadeia de comando e como ela interage com a Justiça Militar do Brasil. Palestra proferida pelo Ministro Almirante de Esquadra Marcos Augusto Leal de Azevedo no Seminário Internacional de Direitos Humanos e a Administração da Justiça Pelos Tribunais Militares organizado pelo Alto Comissariado dos Direitos Humanos das Nações Unidas, pelo Ministério das Relações Exteriores do Brasil e pelo Superior Tribunal Militar do Brasil, em Brasília, Distrito Federal, no dia 28 de novembro de 2007.

Conforme adverte o Ministro José Coêlho Ferreira, "a Justiça Militar Estadual não é uma criação recente. Desde 1892 já havia no Estado de São Paulo a Auditoria da Força Pública, composta de um Auditor e de Conselhos de Justiça. As decisões do órgão eram revistas pelo Presidente do Estado, cargo que corresponde ao atual Governador de São Paulo. A situação perdurou até o ano de 1936. Com o advento da Lei Federal $n^{\circ}$ 192, de 17 de janeiro daquele ano, foi criada a Justiça Militar nos Estados. O Governo do Estado, através da Lei Estadual $n^{\circ} 2.856$, de 8 de janeiro de 1937, criou o Tribunal de Justiça Militar, com a denominação de Superior Tribunal de Justiça Militar. A sua denominação atual é Tribunal de Justiça Militar do Estado de São Paulo e, desde a Emenda $n^{\circ} 2$ à Constituição do Estado, de 30 de outubro de 1969, é composto de cinco (5) juízes, sendo três civis e dois militares.

No Rio Grande do Sul, com fulcro na Lei Federal $n^{\circ} 3.351$, de 3 de outubro de 1917, que autorizou o julgamento dos oficiais e das praças das Policias por elementos das suas Corporações nos crimes propriamente militares, foi criada a Justiça Militar estadual por força do Decreto $n^{\circ}$. 2.347-A, de 28 de maio de 1918, que estabeleceu os Conselhos de Disciplina, organizados extraordinariamente, o Conselho Militar permanente, para o primeiro grau, e, como instância revisora, o Conselho de Apelação, composto por cinco membros: o Comandante-Geral da Brigada (que deveria presidi-lo), três oficiais militares, convocados por este, e um juiz togado, nomeado pelo Presidente do Estado, atual Governador do Estado do Rio Grande do Sul.

A Lei Federal $n^{\circ}$ 192, de 17 de janeiro de 1937, procurou sistematizar melhor a matéria, autorizando expressamente os estados-membros a instituirrem a Justiça Militar estadual. Por conta disso, o Decreto-Lei $n^{\circ} 47$, de 19 de novembro de 1940, fixou a Lei Orgânica da Justiça Militar do Estado do Rio Grande do Sul, convertendo o Conselho de Apelação em Corte de Apelação e, finalmente, atribuindo aos seus membros garantias de magistrados, tais como vitaliciedade e irredutibilidade de vencimentos. A Corte continuava composta por cinco membros, porém, agora todos eram nomeados pelo Governador do Estado. No primeiro grau, foram instituidos dois Conselhos: o Especial, para julgar oficiais, e o Permanente, para julgar as praças. A Lei n. 6.156/70, manteve a Corte de Apelação com cinco membros, dos quais, um civil. O Código de Organização Judiciária do Estado do Rio Grande Sul (Lei Estadual n. 7.356/80), de 01 ${ }^{\circ}$ de fevereiro de 1980, fixou a composição do Tribunal de Justiça Militar do Estado do Rio Grande do Sul em sete juízes, quatro militares e três civis, todos nomeados pelo Governador, sendo esta a composição atual.

Em Minas Gerais, a Justiça Militar foi criada pela Lei $n^{\circ}$ 226, de 09 de novembro de 1937. Naquela época, compunha-se, apenas, de um Auditor e de Conselhos de Justiça, especiais ou permanentes. Na falta de um órgão próprio de segundo grau, a jurisdição era exercida pela Câmara Criminal da Corte de Apelação, hoje, Tribunal de Justiça.

Em 1946, através da Lei de Organização Judiciária do Estado e Regimento de Custas (Decreto-lei $n^{\circ} 1.630$, de 15/01/46) foi ela reestruturada, com a criação do então chamado Tribunal Superior de Justiça Militar, sediado na Capital, como órgão de segundo grau de jurisdição, composto de três juízes, sendo um civil e dois militares, nomeados pelo Governador do Estado. A Lei $n^{\circ}$. 1.098, de 22 de junho de 1954, aumentou o número de juizes componentes do Tribunal de Justiça Militar para cinco, sendo três militares e dois civis. A Resolução $n^{\circ}$ 61, de 08 de dezembro de 1975, do Tribunal de Justiça, manteve o mesmo número de juízes, 
castrense processar e julgar civis, somente, militares; mas tal qual a Justiça da União, trata-se de órgão especializado do Poder Judiciário, possuidor de conhecimento e experiência para manejar litígios relacionados à caserna, cujos pilares são a hierarquia e a disciplina.

Ocorre que, a Justiça Militar estadual sofreu modificações significativas com a Emenda Constitucional $n^{\circ} 45 / 2004$. Citem-se, a título de exemplo, a inclusão do juiz de direito como órgão da Justiça Militar, a transferência da presidência dos Conselhos ao juiz togado, a ampliação de sua competência para julgar atos de natureza punitivo-disciplinar e a transferência para o tribunal do júri do julgamento dos crimes dolosos contra a vida praticados por militar contra civil. Ressalve-se, contudo, que permanece na esfera de competência do Juízo Militar dos Estados processar e julgar os crimes dolosos contra a vida cometidos por militar contra militar.

À evidência, o constituinte derivado limitou sua atuação à esfera dos entes federados, não alterando os dispositivos constitucionais concernentes à União. Disto resultou uma assimetria no tocante às competências dos Juízos, vez que, por força do artigo 124 do Texto Fundamental, a Justiça Militar da União não aprecia as punições disciplinares militares no âmbito das Forças Armadas.

Buscando reparar tal omissão, tramita no Congresso Nacional a Proposta de Emenda Constitucional 358/2005, apresentada pelo Senado Federal, com vistas a dar continuidade à reforma do Poder Judiciário. O texto modifica a composição do Superior Tribunal Militar e alarga sua competência autorizando-o a apreciar as punições disciplinares aplicadas aos membros das Forças Armadas. ${ }^{14}$

Sem dúvida, a ampliação da competência da Justiça Castrense Federal para exercer o controle jurisdicional sobre as punições disciplinares aplicadas aos membros das Forças Armadas, ${ }^{15}$ terá o condão de dirimir os sucessivos conflitos

composição que se mantém até os dias atuais." In: Palestra proferida em 28/09/2006, no I Seminário Jurídico ESPMU/MPM- Paraná e Rio Grande do Sul.

Atuando na $2^{\mathrm{a}}$ instância, existem três Tribunais Militares Estaduais localizados em São Paulo, Rio Grande do Sul e Minas Gerais, instituídos consoante o disposto no $\S 3^{\circ}$, do art. 125 da Lei Maior, a saber; contarem os respectivos estados com efetivo militar superior a vinte mil integrantes. Nas demais unidades federativas, os policiais militares e bombeiros são julgados, em primeiro grau, pelas Auditorias Militares, com recurso para os Tribunais de Justiça Estaduais.

14 Segundo observa Jéssica da Silva Rodrigues: "o que não pode ocorrer é, um mesmo texto normativo, sobretudo aquele que se constitui na fonte de validade das demais normas jurídicas, abarcar essa disparidade de competências, onde a mesma matéria pode ser analisada pela justiça especial ou pela justiça comum, a depender da parte envolvida: se membro das Forças Armadas ou das Forças Auxiliares. Não há dúvidas de que, se aprovada a PEC n ${ }^{\circ} 358 / 2005$, serão necessárias diversas adaptações, tais como a exigência das ações da cobrança de custas, o preparo dos processos, valor da causa, vez que essa nova jurisdição não será gratuita, impondo a necessidade de imediata adaptação da Lei de Organização Judiciária Militar. Ademais, o Ministério Público Militar deixará de exercer seu papel estritamente penal, para atuar em suas diversas atribuições conferidas constitucionalmente no art. 127." In: O controle jurisdicional do ato disciplinar militar no âmbito das Forças Armadas. Monografia apresentada à Faculdade de Direito do Centro Universitário de Brasília, 2008, p. 71.

15 Define a Lei $\mathrm{n}^{\circ} 6.880 / 80$ — E Estatuto dos Militares—o conceito legal de disciplina, em seu art. 14, $\S 2^{\circ}$. A punição disciplinar é cabível em decorrência da violação das obrigações ou dos deveres militares. A administração militar, no âmbito de cada Força, classificou e especificou em seus Regulamentos Disciplinares as 
instaurados junto à Justiça Federal que, nos termos do art. 109 da Grande Norma, deve apreciá-los em razão do vínculo funcional dos militares com a União. ${ }^{16}$

No momento, conforme destacou a Desembargadora Marga Tessler, ${ }^{17}$ a fratura de competências tem fragilizado o Poder Judiciário porque compromete a eficácia, a segurança e a certeza dos julgados ao desuniformizar a jurisprudência. A padronização das decisões emanadas de uma justiça especial, inegavelmente, mais preparada para lidar com as causas que envolvam seus membros, prestigia o exercício da Jurisdição. Insofismável a constatação de que, sendo a Justiça Militar uma justiça especializada, tal qual a do Trabalho e a Eleitoral, é ela quem detém a expertise para assegurar a incolumidade dos bens jurídicos tutelados pela lei material penal, bem como para avaliar a legalidade do exercício do poder disciplinar militar.

Destacam-se, ademais, no cenário legislativo novas alterações legais quanto à competência da Justiça Castrense. A Lei no 13.491 de 13 de outubro de 2017, implementou várias mudanças, notadamente no que concerne a ampliação do conceito de crimes militares, com a alteração do inciso II do art. $9^{\circ}$ do CPM. O dispositivo foi adicionado com uma nova categoria de delitos impropriamente castrenses, em observância ao critério ratione legis, devendo para serem processados e julgados no foro penal especial, analisados de acordo com as circunstâncias e os sujeitos ativos.

Para além, foi promulgada a Lei n ${ }^{\circ}$ 13.774, em 19 de dezembro de 2018, que alterou a nomenclatura dos magistrados militares - anteriormente conhecidos como Juízes-Auditores, para Juízes federais da Justiça Militar da União-, atribuindo-lhes competência exclusiva para presidir os Conselhos de Justiça; processar e julgar

hipóteses de aplicação da referida punição, vg: Decreto $n^{\circ}$ 88.545, de 26/07/1983 (Regulamento Disciplinar da Marinha), art. 6 ${ }^{\circ}$; Decreto ${ }^{\circ} 4.346$, de 26/08/2002 (Regulamento Disciplinar do Exército), art. 14 e Decreto $n^{\circ} 76.322$, de 22/09/1975 (Regulamento Disciplinar da Aeronáutica), art. $8^{\circ}$. As punições previstas nos Regulamentos Disciplinares Militares para as transgressões são, em geral, com algumas distinções: advertência, repreensão, detenção, prisão, licenciamento e exclusão a bem da disciplina. Apesar de suas peculiaridades, as sanções disciplinares são espécies de sanções administrativas. Tem por escopo resguardar os valores que regem a Administração Pública como um todo.

16 Sobre a discussão, decisão do STF, de relatoria do Ministro Ricardo Lewandowski:

EMENTA: RECURSO ORDINÁRIO EM HABEAS CORPUS. PROCESSUAL PENAL.

INFRAÇÃO DISCIPLINAR. PUNIÇÃO IMPOSTA A MEMBRO DAS FORÇAS ARMADAS. CONSTRIÇÃO DA LIBERDADE. HABEAS CORPUS CONTRA O ATO.

JULGAMENTO PELA JUSTIÇA MILITAR DA UNIÃO. IMPOSSIBILIDADE.

INCOMPETENNCIA. MATÉRIA AFETA Aे JURISDIÇÃO DA JUSTIÇA FEDERAL COMUM. INTERPRETAÇÃO DOS ARTS. 109, VII, e 124, \& $2^{\circ}$.

I- À Justiça Militar da União compete, apenas, processar e julgar os crimes militares definidos em lei, não se incluindo em sua jurisdição as ações contra punições relativas a infrações (art.124, $\S 2^{\circ}$, da CF).

II - A legalidade da imposição de punição constritiva da liberdade, em procedimento administrativo castrense, pode ser discutida por meio de habeas corpus. Precedentes.

III- Não estando o ato sujeito a jurisdição militar, sobressai a competência da Justiça Federal para o julgamento de ação que busca desconstituí-lo (art. 109, VII, CF).

$I V$ - Reprimenda, todavia, já cumprida na integralidade.

V - HC prejudicado." $1^{\mathrm{a}}$ Turma. RHC no 88543. DJ de 27.4.07.

17 TESSLER, Marga Inge Barth. A competência da Justiça Militar da União com a provável aprovação da PEC $\mathrm{N}^{\circ} 358 / 2005$. Revista Direito Militar, $\mathrm{n}^{\circ}$ 62, novembro/dezembro, 2006, pp. 16-18. 
monocraticamente os civis e, também, os militares, quando estes forem acusados juntamente com os primeiros no mesmo processo, ex vi dos incisos I e II do art. $9^{\circ}$ do CPM. Compete-lhes, outrossim, julgar o habeas corpus, o habeas data os mandados de segurança contra ato de autoridade militar praticado em razão da ocorrência de crime militar, exceto se praticado por oficial-general, cuja atribuição originária é do STM.

Na mesma senda, a referida norma alterou a antiga Auditoria de Correição, agora denominada Corregedoria da Justiça Militar, função dantes exercida por Juiz-Auditor, auxiliado por servidores da primeira instância castrense, sendo subsumida ao Ministro Vice-Presidente do Superior Tribunal Militar, já agora na função de Ministro-Corregedor, tendo sido incorporados os servidores da Auditoria aos quadros do STM.

Fato é que, a celeridade judicial é imperiosa para a preservação da hierarquia e disciplina dentro dos quartéis.

A Justiça que tarda, falha. E em se tratando do Direito Penal Militar, a morosidade processual pode revelar-se fatal para a integridade das Forças Armadas, instituições nacionais permanentes, conforme se extrai da dicção constitucional. São elas as únicas que têm por finalidade a defesa da Pátria, valor mais elevado do que a própria vida, posto que, em determinadas circunstâncias, impõem-se aos militares o dever de matar ou morrer. A tal valor especialíssimo, correspondem regras especialíssimas, que devem ser rigorosamente observadas, sob pena de comprometimento do próprio Estado Democrático de Direito.

Adicione-se a mobilidade, outra característica inerente à Justiça Militar, vislumbrar-se imponderável em se tratando da Justiça Federal Comum. Inconcebível em situações de conflitos armados, o deslocamento da Justiça Federal para teatros de operações de guerra, onde o poder disciplinar militar se faz mais premente; a uma, porque o Comandante não pode praticá-lo de forma abusiva ou ilegal, a duas, porque os crimes cometidos em situação tão dramática determinam uma pronta, ativa e ágil estrutura judiciária, que permita apurar os delitos e punir os culpados com a maior brevidade de tempo possível.

\section{OS DESAFIOS DA JUSTIÇA MILITAR DA UNIÃO BRASILEIRA}

Resta apontar os desafios e as perspectivas a serem enfrentados pela Justiça Militar, a Justiça mais antiga do Brasil, na contemporaneidade.

O primeiro embate é a superação do estigma de "justiça corporativa". As estatísticas referentes à Justiça Militar Federal revelam o seu rigor na aplicação da lei penal castrense, inadmitindo a impunidade dos acusados quando efetivamente comprovadas a autoria e a materialidade do ato delitivo. Assim, o escopo judicial objetiva proteger a Instituição Castrense e os princípios que a norteiam: a hierarquia e a disciplina. E não poderia ser de diferente. Os militares, ao contrário dos civis, detêm as armas da Nação; seu contingente é de aproximadamente 310.000 jurisdicionados - 220.000 no Exército, 55.000 na Aeronáutica e 55. 000 na Marinha. Temerário, pois, para a Democracia, a inobservância de paradigmas rígidos de 
conduta, afinal, quando as Forças Armadas se desorganizam, tornam-se impotentes para cumprirem sua missão constitucional de defender a Pátria, pondo em risco a soberania do Estado e a estabilidade do regime político. Está-se a lidar com valores singulares, por isso mesmo, tutelados pelo Constituinte Maior e pelo legislador como bens jurídicos a serem resguardados pela ordem normativa e social. Daí decorre, a importância da Justiça Militar da União como justiça especializada.

Ocorre, porém, que apesar de sua relevância e de o Superior Tribunal Militar ter mais de dois séculos de existência, há um profundo desconhecimento por parte da sociedade e, o que é mais grave, dos próprios operadores do Direito, sobre sua competência e atuação. Confundida muitas vezes com as justiças militares estaduais, supõe-se, não raro, ser a Corte Militar Federal responsável pelo julgamento das Forças Auxiliares - policiais militares e bombeiros- juntamente com os integrantes das Forças Armadas. Ademais, é comum atribuir-lhe a pecha de tribunal de exceção quando da vigência dos regimes autoritários no país. Nada mais equivocado. Atesta a história brasileira sua imparcialidade e isenção em decisões memoráveis, tal qual a prolatada pelo então Supremo Tribunal Militar, quando reformou sentença condenatória proferida contra João Mangabeira pelo Tribunal de Segurança Nacional do Estado Novo, concedendo-lhe a ordem de habeas corpus - $\mathrm{HC} \mathrm{n}^{\circ}$. 8.417, de 21 de junho de 1937- ou ainda, quando deferiu medida liminar em sede deste mesmo writ constitucional; primeira Corte a fazê-lo, servindo tal decisão de precedente para o Supremo Tribunal Federal - HC $\mathrm{n}^{\mathrm{o}} 41.296$, de 14 de novembro de 1964 . $^{18}$

Lamentavelmente, tal desconhecimento levou a Emenda Constitucional $n^{\circ} 45 / 2004$ a olvidar o assento que a Justiça Militar da União faz jus no Conselho Nacional de Justiça, omissão que tanto a PEC 358/2005, ${ }^{19}$ como a PEC

18 Outros exemplos poderiam ser mencionados para ilustrar a trajetória dignificante da Justiça Militar da União. Rememore-se o caso da incomunicabilidade dos presos, proibidos de manter contato com seus advogados sob a égide da Lei de Segurança Nacional e que teve, na histórica decisão da Representação ${ }^{\circ}$ 985, correta e precursora solução, ao observar os princípios do direito defesa. Do mesmo modo, decidiu o STM na década de 1970 que a greve, mesmo quando declarada ilegal pelo Poder Executivo, se perseguisse objetivos de melhoria salarial não se traduzia, segundo o R.C n ${ }^{\circ} 5385-6$, em crime contra a segurança nacional. Ainda, no R.C $n^{\circ} 38.628$ assentou a Corte Militar que a mera ofensa às autoridades constituídas, embora expressa em linguagem censurável passou a não mais tipificar crime contra a segurança do Estado.

As decisões aqui referidas, dentre outras que poderiam ser elencadas, conferiram incensuráveis desates e exata dimensão jurídica sobre temas que constantemente se prestavam a interpretações dúbias. Sem dúvida, está-se diante de jurisprudência dignificante que, ao sobrepor-se às pressões políticas deixou significativo legado às gerações futuras e ao democratismo do Poder Judiciário. Por fim, saliente-se que os defensores públicos da União quando atuaram pela primeira no Judiciário Pátrio, atuaram no Tribunal Militar Federal. BRASIL. Senado Federal. Proposta de Emenda à Constituição ${ }^{\circ} 358$, de 10 de janeiro de 2005. Altera dispositivos dos arts. 21, 22, 29, 48, 93, 95, 96, 98, 102, 103-B, 104, 105, 107, 111-A, 114, 115, 120, 123, 124, 125, 128, 129, 130-A e 134 da Constituição Federal, acrescenta os arts. 97-A, 105-A, 111-B e 116-A, e dá outras providências. Inclui a necessidade de permanência de 3 (três) anos no cargo para que o magistrado tenha direito à vitaliciedade na função; proíbe a prática de nepotismo nos Tribunais e Juízos; altera a composição do STM e incluindo competências para o STF e STJ; instituindo a "súmula impeditiva de recursos", a ser editada pelo STJ e TST - Reforma do Judiciário. A referida PEC teve seu último andamento em 6/2/2018, com a inclusão na ordem do dia do Plenário, nos termos do art. 114, inciso XIV, do Regimento da Câmara dos Deputados. A justificativa foi que a Reforma do Judiciário, iniciada com a Emenda Constitucional $\mathrm{n}^{\circ}$ 45/2004 estava incompleta. Devido a tal lacuna, encontra-se na Câmara dos Deputados desde o ano de 2005, 
21/2014, ${ }^{20}$ intentaram reparar. Indiscutivelmente, o ingresso da Justiça Castrense Federal no CNJ revela-se medida de direito para reparar tratamento inconstitucional que atenta contra a unidade da Justiça e contra o Poder Judiciário como órgão do Estado.

A importância da jurisdição penal castrense faz-se, pois, imperiosa, para a preservação da autoridade militar na vigilância e subordinação às ordens no interior da corporação. Afinal, como salienta o Ministro Carlos Alberto Marques Soares; "a disciplina é a força e a vida das instituições militares, juntamente com a preservação dos princípios hierárquicos (...)." Tais valores, "necessitam de uma legislação própria e de uma jurisdição especializada que possa dar garantia de sua manutenção. Esse foro especial se constitui na condição da boa administração da Justiça". ${ }^{21}$

Alfim, imprescindível a ampliação da competência, decisiva para a unificação, por pertinência temática, das jurisdições militares, em face da alteração promovida pela EC $\mathrm{n}^{\circ} 45 / 04$, mormente porque, conforme salientado, tanto o crime, quanto a infração disciplinar militar, constituem ofensas à hierarquia e disciplina, princípios basilares não apenas para as Forças Auxiliares, mas, igualmente, para as Forças Armadas.

$\mathrm{O}$ enfrentamento de tais desafios vem ao encontro de um país que vivencia momentos de "redefinições institucionais e de reconstruções jurídicas, em busca de novos paradigmas que sustentem a Justiça como valor social, a transparência como marca de atuação dos órgãos estatais, a agilidade, prontidão, eficácia (...) da ação judiciária e a própria aplicação do direito como elaboração coletiva". ${ }^{22}$ Prestigiar os princípios da cidadania e da dignidade da pessoa humana e renovar a atuação judicial, neutralizada por diversas mazelas que comprometem sua identidade conceitual e axiológica, constitui-se no decisivo contributo da Magistratura para a edificação da nacionalidade, tão acutilada pelas vicissitudes do processo político brasileiro.

A legitimidade da potestade pública, em todas as suas esferas, passa necessariamente pelos foros judiciais. Sobrelevar-lhe a atuação é valorizar a coesão, a congruência e a identidade do sistema constitucional, sem olvidar o que Lassalle chamaria de "os fatores reais do poder".

a PEC n⿳3 358/2005, do Senado Federal, parte remanescente daquela que resultou na aludida Emenda Constitucional. Disponível em: https://www.camara.leg.br/proposicoesWeb/prop_mostrarintegra;jsessionid=4714 9F957B4E0BD8211E736C1E1478AD.proposicoesWebExterno1?codteor=1639230\&filename=TramitacaoPEC+358/2005. Acesso em: 5/2/2019.

20 BRASIL. Senado Federal. Proposta de Emenda à Constituição nº 21, de 2014. Dá nova redação ao art. 103 - B da Constituição Federal. Altera a composição do Conselho Nacional de Justiça, de 15 para 19 membros, para incluir um Ministro do Tribunal Superior Eleitoral, um Ministro civil do Superior Tribunal Militar, um juiz de Tribunal Regional Eleitoral e um Juiz-Auditor da Justiça Militar da União. A mencionada PEC foi arquivada no final da legislatura de 2018, nos termos do art. 332 do Regimento Interno do Senado Federal - RISF, em 28 de dezembro de 2018. Disponível em: https://www25.senado.leg.br/web/atividade/materias/-/ materia/118267. Acesso em: 5/2/2019.

21 In: Justiça Militar da União - 200 Anos, op. cit.

22 ALARCÓN, Pietro de Jesús Lora. Reforma do Judiciário e Efetividade da Prestação Jurisdicional .In: Reforma do Judiciário Analisada e Comentada. Coordenadores: André Ramos Tavares, Pedro Lenza e Pietro de Jesús Lora Alarcón, São Paulo: Editora Método, 2005, p. 28. 
Neste diapasão, a vivência bicentenária da Justiça Militar Federal, cuja trajetória institucional amalgama a História do Brasil, projeta a afirmação do Estado como ethos e o permanente comprometimento do Poder Judiciário com a construção da legitimidade e do democratismo estatal.

\section{BIBLIOGRAFIA}

ALARCÓN, Pietro de Jesús Lora. Reforma do Judiciário e Efetividade da Prestação Jurisdicional.In: Reforma do Judiciário analisada e comentada. Coordenadores: André Ramos Tavares, Pedro Lenza e Pietro de Jesús Lora Alarcón. São Paulo:Editora Método, 2005.

AZEVEDO, Marcos Augusto Leal de. A cadeia de comando e como ela interage com a Justiça Militar do Brasil. Palestra proferida no SEMINÁRIO INTERNACIONAL DE DIREITOS HUMANOS E A ADMINISTRAÇÃO DA JUSTIÇA PELOS TRIBUNAIS MILITARES organizado pelo Alto Comissariado dos Direitos Humanos das Nações Unidas, pelo Ministério das Relações Exteriores do Brasil e pelo Superior Tribunal Militar do Brasil, em Brasília, Distrito Federal, no dia 28 de novembro de 2007.

BANDEIRA, Esmeraldino. Direito, Justiça e Processo Militar. Rio de Janeiro: Francisco Alves, $1^{\circ}$. vol. 1919.

BARBALHO, João. Constituição Federal Brasileira - Comentários. Rio de Janeiro: Briguiet e Cia. Editores, $2^{\mathrm{a}}$ ed., 1924.

BASTOS, CELSO Ribeiro e MARTINS, Ives Gandra. Comentários à Constituição Brasileira (promulgada em 5 de outubro de 1988), $4^{\circ}$ Volume, Tomo III - Arts. 92 a 126. São Paulo:Saraiva, $2^{\mathrm{a}}$ edição, atualizada, 2000.

BASTOS, Paulo César. Superior Tribunal Militar. 173 Anos de História. Brasília, 1981.

CARVALHO JUNIOR, Astor Nina. A segunda etapa da reforma do Judiciário e o novo perfil do Superior Tribunal Militar. In: Revista de Direito Militar, v.10, $n^{\circ} .61$.

DA SILVA RODRIGUES, Jéssica. O controle jurisdicional do ato disciplinar militar no âmbito das Forças Armadas. Monografia apresentada à Faculdade de Direito do Centro Universitário de Brasília, 2008.

FERREIRA, José Coelho. A Jurisdição Cível da Justiça Militar:abrangência e limites dessas nova competência, tanto a nível federal como estadual. Necessidade de reestruturação da Justiça Militar da União. Palestra proferida no I Seminário Jurídico ESMPU/MPM - Paraná e Rio Grande do Sul, na cidade de Curitiba, em 28 de setembro de 2006.

GARCÍA-PELAYO, Manuel. Derecho Constitucional Comparado. Alianza Editorial, S.A, Madrid, 1984.

HABERMAS, Jürgen. Direito e Democracia, entre facticidade e validade, tradução de Flávio Beno Siebeneichler. Rio de Janeiro: Tempo Brasileiro, 1977, vol. II - Direito e Democracia

LASSALLE, Ferdinand. A Essência da Constituição. Tradução de Walter Stönner, prefácio de Aurélio Wander Bastos. Rio de Janeiro: Editora Liber Juris, 1985. 
LOBÃO, Célio. Direito Penal Militar. 3. ed. Brasília: Brasília Jurídica, 2006.

MARINI E SOUZA, Henrique. A Justiça Militar da União. Conferência realizada para oficiais-generais e oficiais superiores das Forças Armadas da República de Angola, em 19 de julho de 2006.

MARQUES SOARES, Carlos Alberto. Justiça Militar da União: 200 Anos. Palestra proferida em Comemoração ao Bicentenário da Justiça Militar Federal, na Auditoria da $9^{\text {a }}$ Circunscrição Judiciária Militar, na cidade de Campo Grande, Mato Grosso do Sul, em 13 de junho de 2008.

MIRANDA, Jorge. Manual de Direito Constitucional - Introdução à Teoria da Constituição. Tomo II, $2^{a}$ ed. (reimpressão), Coimbra Editora, Limitada, 1988.

NAKHNIKIAN, George. El Derecho y las Teorías Éticas Contemporáneas. Tradução de Eugenio Bulygin y Genaro R. Carrió. México: Distribuciones Fontamara, S.A, 1993.

TESSLER, Marga Inge Barth. A competência da Justiça Militar da União com a provável aprovação da PEC $N^{o}$. 358/2005. In: Revista Direito Militar, nº 62, novembro/dezembro, 2006. 